\title{
Osseointegration of zirconia implants with 3 varying surface textures and a titanium implant: A histological and micro-CT study
}

\author{
Paweł Kubasiewicz-Ross ${ }^{A-D}$, Jakub Hadzik ${ }^{C, D}$, Marzena Dominiak ${ }^{D-F}$ \\ Department of Oral Surgery, Wroclaw Medical University, Poland \\ A - research concept and design; $\mathrm{B}$ - collection and/or assembly of data; $\mathrm{C}$ - data analysis and interpretation; \\ $D$ - writing the article; $E$ - critical revision of the article; $F$ - final approval of the article
}

Address for correspondence

Paweł Kubasiewicz-Ross

E-mail: pawelkubasiewicz@wp.pl

\section{Funding sources}

None declared

Conflict of interest

None declared

Received on 0ctober 23, 2016

Reviewed on January 24, 2017

Accepted on March 1, 2017

\begin{abstract}
Background. Zirconium - a bioinert metal - in comparison with titanium implants, offers a variety of potential advantages for use in the esthetic area of dentistry due to its tooth-like color. Zirconium dental implants are considered to be an alternative method of treatment to conventional titanium dental implants for patients with a thin gingival biotype.
\end{abstract}

Objectives. This study was designed to study the bone tissue response to new zirconia implants with modified surfaces in comparison with commercially available titanium dental implants and commercially available zirconia implants.

Material and methods. The study was carried out on a group of 12 16-month-old minipigs. New zirconia implants with 3 different surfaces were used: M1 - blasted surface, $\mathrm{M} 2$ - etched surface and M3 - blasted and etched surface (Maxon Motor GmbH, Sexau, Germany) and compared to conventional titanium implants with an sandblasted and acid etched (SLA) surface (Straumann GmbH, Freiburg, Germany) and commercially available zirconia implants (Ziterion GmbH, Uffenheim, Germany). Histological and micro-computed tomopgraphy (micro-CT) evaluation was performed.

Results. In the micro- $C$ T assessment, the average bone-implant contact (BIC) of the zirconia experimental implants was $41.44 \%$. In particular, the BIC\% for M1 was 39.72\%, for M2 it was 43.97\%, and for M3 - 40.63\%; in the control group it was $49.63 \%$ and $27.77 \%$ for ceramic and titanium control implants, respectively. The intra-group analysis showed no statistically important differences between the BIC values for implants in any group. However, the analysis of BIC for different regions of the same implant showed statistically significant differences in all of the groups between the results of the threaded region and the neck and the apex.

Conclusions. The results of our study suggest that zirconia implants with modified surfaces display features of osseointegration similar to those of titanium implants. These results are promising in using zirconia implants for dental applications in the future.

Key words: dental implants, osseointegration, micro-computed tomography, histomorphometry, zirconia implant

DOI

10.17219/acem/69246

Copyright

Copyright by Author(s)

This is an article distributed under the terms of the

Creative Commons Attribution Non-Commercial License

(http://creativecommons.org/licenses/by-nc-nd/4.0/) 


\section{Introduction}

Titanium implants are considered the gold standard of modern dental implantology. This is due to their long, traceable record of predictable clinical performance, excellent biocompatibility and mechanical properties, ability to osseointegrate, and to the fact that titanium implants are easy to produce. ${ }^{1}$ However, titanium still bears several esthetic disadvantages, especially in the case of periodontia with a thin biotype in the esthetically-sensitive anterior area of the jaw. If a titanium implant is used in such a case, the mucosa in the neck area of the implant may become grayish, which consequently limits the success of the overall treatment. Titanium implants may also require additional surgical procedures concerning soft tissue augmentation, e.g., connective tissue grafting, which aims at widening and thickening keratinized tissue. ${ }^{2}$ A less frequent, though possible, drawback is that titanium might be an allergen and may diffuse not only within the adjacent tissues - as is proven by the elevated concentrations found in the vicinity of oral implants and in regional lymph nodes - but also systemically. ${ }^{3}$ As a possible alternative to titanium, ceramic materials have already been investigated and clinically used for years in the field of oral implantology.

Due to its good osseointegrative properties, the first ceramic material used in implantology was aluminum oxide. ${ }^{4}$ In follow-up examinations after 10 years, the success of those implants was between $87 \%$ and $92.5 \%$. ${ }^{4,5}$ Systems based on aluminum oxide were used for immediate implantation in the cases of single tooth loss in the jaw, in the area of the incisors, canines, and premolars, i.e., in the areas where chewing forces are relatively weak. Even though implants were used in the above-mentioned clinical circumstances, there were cases of damage caused by chewing. Hence, because of inadequate mechanical strength, aluminum-oxide implants are no longer in use. Zirconium is another alternative material initiated by general medicine, mainly orthopedics.

A small number of complications, good chemical parameters, anticorrosion properties, mechanical strength, an elasticity module close to that of steel, and biocompatibility in particular made zirconium a perfect material for implants. ${ }^{6}$

Zirconium, a bioinert, non-resorbable metal, offers a variety of potential advantages over titanium implants for use in the esthetic area of dentistry due to its toothlike color. Its surface texture can be modified and it does not show any chemical or physical bonding with plaque. ${ }^{7}$ Furthermore, good scientific results in osseointegration comparable to titanium implants have been shown. ${ }^{7}$

\section{Material and methods}

\section{Dental implants}

The following newly-designed zirconia implants were used: - ø4.0 × $10 \mathrm{~mm} \mathrm{ZrO}_{2}$ ceramic implant with blasted surface (Maxon Motor GmbH, Sexau, Germany) - M1;
- $\varnothing 4.0 \times 10 \mathrm{~mm} \mathrm{ZrO}_{2}$ ceramic implant with etched surface (Maxon Motor GmbH, Sexau, Germany) - M2;

- $\varnothing 4.0 \times 10 \mathrm{~mm} \mathrm{ZrO}_{2}$ ceramic implant with blasted and acid etched surface (Maxon Motor GmbH, Sexau, Germany) - M3.

For a control group, we decided to choose titanium implants with well-established osseointegration properties:

- $\varnothing 4.1 \times 10 \mathrm{~mm}$ Titanium standard implant SLA ${ }^{\circledR}$ (Straumann GmbH, Freiburg, Germany);

- $ø 4.0 \times 10 \mathrm{~mm} \mathrm{ZrO}_{2}$ ceramic implant (Ziterion $\mathrm{GmbH}$, Uffenheim, Germany).

\section{Experimental design and surgical procedure}

The study was performed on 12 16-month-old minipigs with an average weight of 50-60 kg. The study protocol was approved by the commission for animal studies.

The pigs underwent the removal of the permanent premolar teeth 2 months after the extraction of the deciduous premolar teeth in the jaw. Care was taken to avoid bone wall fractures. The extractions, implantations and euthanasia were performed under general anesthesia by intravenous application of pentobarbital (Vetbutal ${ }^{\circledR}$, Biowet Puławy, Poland) at doses of $25 \mathrm{mg} / \mathrm{kg}$ along with the premedication ketamine (Ketamina 10\%, Biowet Puławy, Poland) and local infiltration of $2 \%$ lignocaine with noradrenaline 1:200,000 (Polfa, Poland). Eight weeks after the extractions, a total of 60 implants were inserted in the 12 animals. Each pig was to receive 5 implants (1 per surface state and 2 reference implants) in the mandible (Fig. 1, 2). The position of the implants was statistically fully randomized. The implants were placed endosseously under continuous water cooling. After the insertion, the flap was repositioned using resorbable sutures (4/0 Monosyn ${ }^{\circledR}$, B. Braun, Melsungen, Germany).

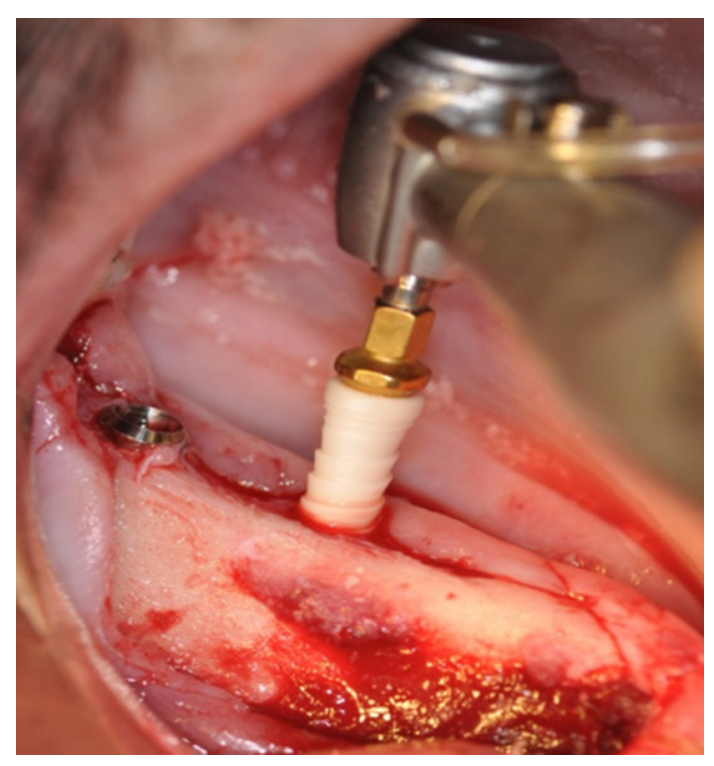

Fig. 1. Insertion of the ceramic implant 


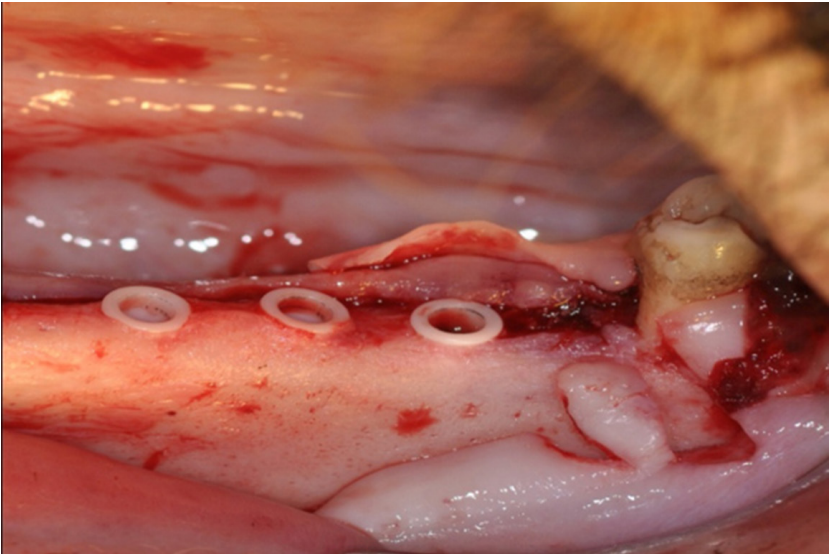

Fig. 2. Three ceramic implants inserted into the alveolar ridge

The animals were euthanized 12 weeks post-implantation using $50 \mathrm{mg} / \mathrm{kg}$ of pentobarbital (Morbital) and block biopsies of the implant sites were collected.

\section{Micro-CT evaluation}

In the micro-CT evaluation, the implant surfaces were divided into 3 regions of interest (ROI). The $1^{\text {st }}$ one was the neck region, the $2^{\text {nd }}$ was the thread area, and last one was the apex region of the implant. The bone-implant contact (BIC) was calculated separately for each ROI. The research was done with a SkyScan 1172 Micro-CT (Bruker, Kontich, Belgium). The exposure was performed with $50 \mathrm{kV}$ of voltage and $10 \mathrm{~W}$ of power. The detection was done on a 12 bit CCD camera. The BIC was calculated using Adobe ${ }^{\circledR}$ PhotoShop ${ }^{\circledR}$ (San Jose, USA). At first, the total length of the vertical cross-section was achieved; next, the length of the cross-section of the implant in direct contact with the bone structure was calculated; and finally, the BIC was counted as a percentage of its proportions.

\section{Histology}

For histological examination, each bone-implant specimen was placed in $4 \%$ phosphate-buffered saline (PBS)buffered formalin, dehydrated in a graded series of alcohol and embedded in methylmethacrylate (Technovit 9100 New $^{\circledR}$, Kulzer, Germany), as described previously. ${ }^{8-11}$ For staining the bone-implant, specimens were cut using a diamond saw and ground to a thickness of approx. $100 \mu \mathrm{m}$ with a grinding system (Exakt Apparatebau, Norderstedt, Germany) as described by Donath and Breuner. ${ }^{12}$ The specimens were then stained with Masson-Goldner trichrome (Merck KGaA, Darmstadt, Germany). for differentiation between collagen and bone tissue, and a histomorphometric analysis was performed by light microscopy. A blind test was conducted at the same time, using identical staff, equipment and chemicals.

\section{Statistical analysis}

For all tested variables, the distribution type was checked. The Shapiro-Wilk test was applied with a significance level of $p=0.05$. For measurable variables, arithmetic averages and standard deviations were calculated. Because none of the cases had a normal distribution, the analysis of variance (ANOVA) Kruskal-Wallis test was applied. At first, the calculation was performed for a significance level of $\mathrm{p}<0.05$; in the cases where $\mathrm{p}<0.05$, a pair-wise comparison was conducted and a new p-value for every significantly different pair was presented. The dependence between the results of radiological and histological evaluation was calculated with the application of Pearson's correlation coefficient and by calculating the ratio between both values. The analysis was performed with R-project (Auckland, New Zeland) and MedCalc (MedCalc Software, Ostend, Belgium).

\section{Results}

Postoperatively, all animals recovered quickly, returning to routine activities such as grooming, eating and drinking within $48 \mathrm{~h}$. Regardless of the material used, there were no macroscopic or microscopic signs of cellular inflammation or implant rejection in any of the test groups.

\section{Results of the micro-CT investigation}

In the radiological assessment, the average $\mathrm{BIC} \%$ of the zirconia experimental implants was $41.44 \%$. In particular, the $\mathrm{BIC} \%$ for $\mathrm{M} 1$ was $39.72 \%$, for M2 it was $43.97 \%$ and for M3 - 40.63\% (Fig. 3-5); in the control group it was $49.63 \%$ and $27.77 \%$ for the ceramic and titanium control implants, respectively (Fig. 6, 7). The distribution of BIC according to the ROI for particular groups is featured in Table 1.

The intra-group analysis showed no statistically significant differences between the BIC values for implants in any group, though the analysis of BIC for different ROIs of the same implant showed statistically significant differences in all of the groups between the results of the threaded region and the neck and the apex. In all groups apart from M1, statistically important differences were seen between the results of BIC for the neck and apex regions (Table 2). The intergroup analysis of the BIC results showed

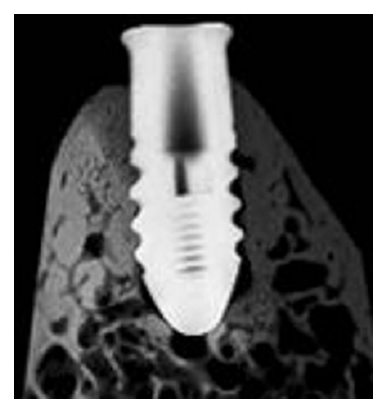

Fig. 3. Micro-CT scan of the M1 implant 


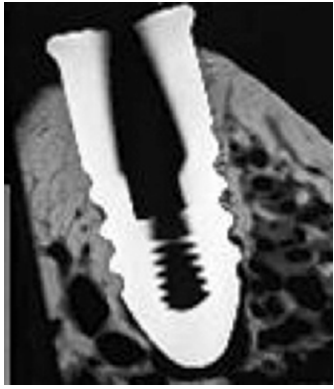

Fig. 4. Micro-CT scan of the M2 implant

significant differences for the threaded region between groups 1, 2 and 3 and group 5 . There were no statistically significant differences between group 4 and the rest of the groups. In the apex region, statistically significant differences were seen between the ceramic control implants and others; additionally, differences were seen for M1/M2 and M1/titanium controls, but without statistical significance.

\section{Results of the histological investigation}

The mandibular bone texture showed typical spongious bone structures. Interconnecting areas of mineralization and osteoid formation between the host bone and the implant surface were detected for all surface states. The formation of woven bone was present within the implant threads of all tested and reference implants (Fig. 8). The bone structure almost completely covered the surface of dental implants, although areas of a well-vasculated medulla could be seen. In the regions mentioned, osteogenic cell lines were found. In most cases, the remodeling process was apparent, the old trabeculae were replaced with a new bone structure. No signs of inflammation were seen in any of the specimens. Test implants were present in the crestal implant area, a tightly surface-adapted connective tissue. The periosteal fibers were in direct contact with the surface and showed parallel fiber orientation. Bordering the connective tissue zone, the bone lamellae extended to the apical region and formed a close BIC. In contrast, using the reference ceramic implant, some resorption at the crestal bone level was observed and the bone appeared rounded down. In the test group, the different characteristics of the bone structure in the apex region could be seen

Table 1. The distribution of the bone-implant contact (BIC) according to the region of interest ( $\mathrm{ROI})$

\begin{tabular}{|l|c|c|c|} 
Group No. & $\begin{array}{c}\text { Bone-implant } \\
\text { contact in neck } \\
\text { region [\%] }\end{array}$ & $\begin{array}{c}\text { Bone-implant } \\
\text { contact in thread } \\
\text { region [\%] }\end{array}$ & $\begin{array}{c}\text { Bone-implant } \\
\text { contact in apex } \\
\text { region [\%] }\end{array}$ \\
\hline M1 & 25.25 & 66.75 & 27.16 \\
\hline M2 & 23.83 & 72.91 & 35.16 \\
\hline M3 & 21.41 & 68.83 & 31.66 \\
\hline Control 1 & 5.41 & 77.91 & 65.58 \\
\hline Control 2 & 7.41 & 42.66 & 33.25 \\
\hline
\end{tabular}

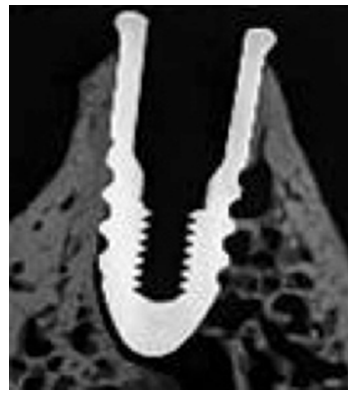

Fig. 5. Micro-CT scan of the M3 implant

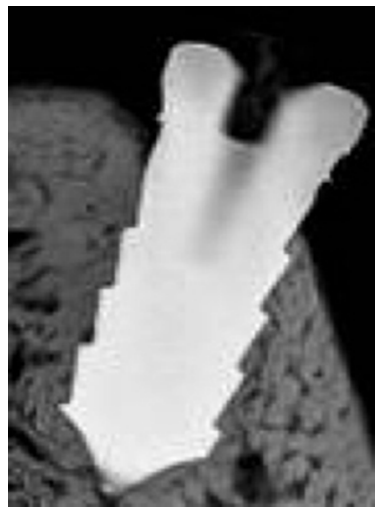

Fig. 6. Micro-CT scan of the zirconium control implant

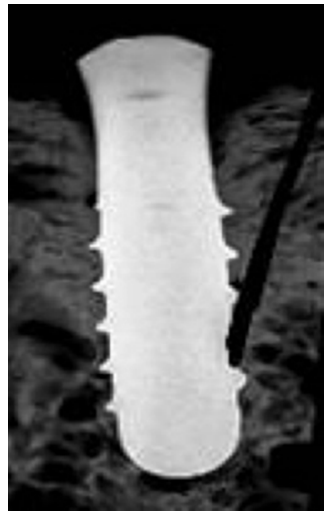

Fig. 7. Micro-CT scan of the titanium control implant

upon histological examination. In the above-mentioned ROI, relatively thin bone trabeculae with highly vasculated medulla areas were noted (Fig. 9). Furthermore, fibrous connective tissue was quite commonly in direct contact with the implant surface. The number of samples with fibrous connective tissue is shown in Table 3. The BIC calculated in the histological analysis is shown in Table 4.

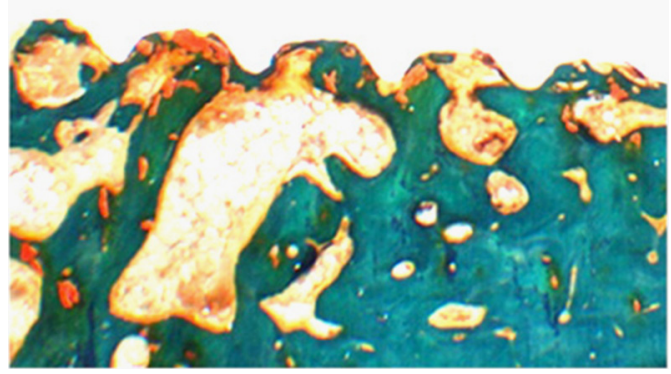

Fig. 8. The formation of woven bone presented within the implant threads 
Table 2. Intragroup analysis of variance between the BIC parameters for different ROI in micro-CT examination

\begin{tabular}{|c|c|c|c|c|c|c|}
\hline \multirow[b]{2}{*}{$\mathrm{ROI}$} & \multirow{2}{*}{$\begin{array}{l}\text { Implant } \\
\text { group (n) }\end{array}$} & M1 & M2 & M3 & Ceramic control & Titanium control \\
\hline & & $\begin{array}{l}\text { significantly } \\
\text { differed from }\end{array}$ & $\begin{array}{l}\text { significantly differed } \\
\text { from }\end{array}$ & $\begin{array}{l}\text { significantly differed } \\
\text { from }\end{array}$ & $\begin{array}{l}\text { significantly differed } \\
\text { from }\end{array}$ & significantly differed from \\
\hline Apex & 12 & $\begin{array}{c}\text { (thread) } \\
p<0.0001\end{array}$ & $\begin{array}{c}\text { (neck) (thread) } \\
p<0.001 \\
\text { for neck } \\
p<0.0001 \\
\text { for thread }\end{array}$ & $\begin{array}{c}\text { (neck) (thread) } \\
p<0.01 \\
\text { for neck } \\
p<0.0001 \\
\text { for thread }\end{array}$ & $\begin{array}{c}\text { (neck) (thread) } \\
p<0.0001 \\
\text { for both }\end{array}$ & $\begin{array}{c}\text { (neck) (thread) } \\
p<0.0001 \\
\text { for neck } \\
p<0.01 \\
\text { for thread }\end{array}$ \\
\hline Neck & 12 & $\begin{array}{c}\text { (thread) } \\
p<0.0001\end{array}$ & $\begin{array}{c}\text { (apex) (thread) } \\
p<0.001 \\
\text { for apex } \\
p<0.0001 \\
\text { for thread }\end{array}$ & $\begin{array}{c}\text { (apex) (thread) } \\
p<0.01 \\
\text { for apex } \\
p<0.0001 \\
\text { for thread }\end{array}$ & $\begin{array}{c}\text { (apex) (thread) } \\
p<0.0001 \\
\text { for both }\end{array}$ & $\begin{array}{c}\text { (apex) (thread) } \\
p<0.0001 \\
\text { for both }\end{array}$ \\
\hline Thread & 12 & $\begin{array}{c}\text { (apex) (neck) } \\
p<0.0001 \text { for both }\end{array}$ & $\begin{array}{c}\text { (apex) (neck) } \\
p<0.0001 \\
\text { for both }\end{array}$ & $\begin{array}{c}\text { (apex) (neck) } \\
p<0.0001 \\
\text { for both }\end{array}$ & $\begin{array}{c}\text { (apex) (neck) } \\
p<0.0001 \\
\text { for both }\end{array}$ & $\begin{array}{c}\text { (apex) (neck) } \\
p<0.0001 \\
\text { for apex } \\
p<0.01 \\
\text { for neck }\end{array}$ \\
\hline
\end{tabular}

Table 3. Number of samples with fibrous connective tissue

\begin{tabular}{|c|c|c|c|c|c|}
\hline Implants & M1 & M2 & M3 & Ceramic control & Titanium control \\
\hline Number of samples with fibrous connective tissue, n (\%) & $4(33)$ & $6(50)$ & $3(25)$ & $7(58)$ & $4(33)$ \\
\hline
\end{tabular}

Table 4. Average of BIC\% according to histomorphometry

\begin{tabular}{|c|c|c|c|c|c|}
\hline Implants & M1 & M2 & M3 & Ceramic control & Titanium control \\
\hline BIC\% & 46 & 61 & 56 & 58 \\
\hline
\end{tabular}

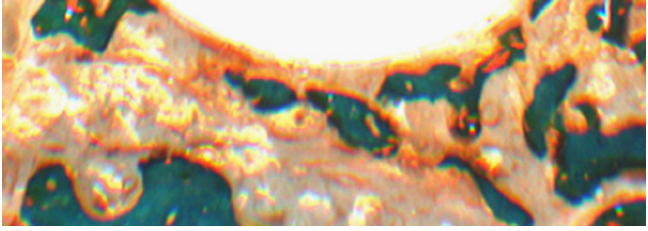

Fig. 9. The apical region of the ceramic implant

The intra-group analysis of the BIC results shows statistically significant differences between group 5 and groups 1 and 2. In the experimental group, the differences between the BIC results of group 1 and groups 2 and 3 were statistically significant (Table 5). Based on the results of the radiological and histological assessment of the BIC, the conclusion can be drawn that the most coherent result was achieved for zirconia implants.

\section{Discussion}

The current definition of osseointegration describes it as the formation of a direct structural and functional conjunction between a dental implant and bone tissue without pathological soft tissue as a mediator.

Osseointegration methods can theoretically be classified into 2 basic types. The $1^{\text {st }}$ group consists of methods where "the functionality of the implant anchorage" is the most important. These are biomechanical methods, where
Table 5. Intra-group analysis of variance in the achieved results of BIC\%

\begin{tabular}{|c|c|c|}
\hline Implant group & $\mathrm{n}$ & Different from \\
\hline M1 & 12 & $\begin{array}{l}\text { (M2) (M3) (titanium control) (ceramic } \\
\text { control) } \\
p<0.0001 \text { for } \mathrm{M} 2 ; \mathrm{p}=0.001 \text { for } \mathrm{M} 3 ; \\
\mathrm{p}<0.0001 \text { for titanium control; } \\
\mathrm{p}<0.0001 \text { for ceramic control }\end{array}$ \\
\hline M2 & 12 & $\begin{array}{c}(\mathrm{M} 1) \\
\mathrm{p}<0.0001\end{array}$ \\
\hline M3 & 12 & $\begin{array}{c}(\mathrm{M} 1)(\text { titanium control) } \\
\mathrm{p}=0.001 \text { for } \mathrm{M} 1 ; \mathrm{p}=0.02 \text { for titanium } \\
\text { control }\end{array}$ \\
\hline Titanium control & 12 & $\begin{array}{c}(\mathrm{M} 1)(\mathrm{M} 3) \\
\mathrm{p}<0.0001 \text { for } \mathrm{M} 1 ; \mathrm{p}=0.02 \text { for } \mathrm{M} 3\end{array}$ \\
\hline Ceramic control & 12 & $\begin{array}{c}(\mathrm{M} 1) \\
\mathrm{p}<0.0001\end{array}$ \\
\hline
\end{tabular}

an experimental trial of pulling an implant out of the bone structure is used (Push and Pull Out Test, Removal Torque Test and Shear Strength Test). The disadvantage of these methods is the complexity of the procedures (which hinders repeatability), the need to transport bone tissue to a specialized laboratory and the fact that preparations are usually stabilized in formalin or other substance after sacrificing the laboratory animal, which may affect the results. ${ }^{13,14}$

The most commonly used and more reproducible methods of evaluating osseointegration quantitatively 
is histomorphometry and micro-CT techniques. Micro$\mathrm{CT}$ is emerging in the field of biomaterial research. Its biggest advantage is its ability to produce 3D images, since histological assessment is 2D. Taking the micro-CT, however, the final result can be interfaced by an artifact layer of various thickness (beam hardening), resulting in the miscalculation of the BIC. ${ }^{15}$ This situation affects titanium implants more than zirconium ones.

Even though the BIC values are a kind of gold standard, the method of calculation varies fundamentally from study to study. Variations like the calculation of the "whole implant surface," the "mineralized bone between 2 threads"16 and the "contact at the best 3 threads"17 are often reported. Most studies, similar to the present work, use the option "from the first to the last bone contact", which allows for a comparison of different screw designs. Different software applications and algorithms are rarely made available to the reader and may lead to inaccurate results.

Sand-blasted and acid-etched titanium implants were considered a control group in our study. The histological parameters of osseointegration have been widely documented in the literature in tests on animal models. Buser et al. achieved BIC results of $78 \%$ for SLActive and $75 \%$ for SLA over 8 weeks of observation. ${ }^{18}$ Schwarz et al., in tests on a dog model, proved the BIC value of SLA implants to be $55 \% .{ }^{19}$ SLA surface implants were also tested in a pig model and the $\mathrm{BIC}$ results showed a rise to $58.5 \% \pm 11.4 \%$ over 8 weeks of healing. ${ }^{20}$

In studies based on an animal model of beagles, a histomorphometric comparative assessment of titanium implant osseointegration with the SLA surface was also performed. ${ }^{21}$ The extraction phase included premolars bilaterally. The healing period of unloaded implants was 2 weeks and the observation period lasted 4 weeks. The BIC values were different in the 2-week observations and amounted to $29 \%$ for SLActive surface and 24\% for control SLA; after 4 weeks of healing, they both reached a value of $39 \%$.

The issue of the histological assessment of zirconium implant osseointegration is still new. One should only consider those studies which include a larger sample of implantations, comply with statistical analysis guidelines and use methodology which includes an assessment of a titanium implant control group in the discussion. ${ }^{18-20}$ In the earliest studies on zirconium implants, the BIC value in an 8-week observation of 156 zirconium implants was $86 \% .^{22}$ This is the only report with such high osseointegration values. In other studies, the BIC value for such implants equaled $45 \%$ or $65 \%$, values which are closer to our own studies. ${ }^{23,24}$ In other studies performed on 28 zirconium implants over a 60-day observation period, the average BIC value was $56 \% .{ }^{25}$ In these studies, very unstable results were achieved, where the difference between the max and min $\mathrm{BIC}$ values was $32 \%$. Scarano et al., in a 4-week observation of 20 implants, reported a BIC value of $68 \% .{ }^{26} \mathrm{With}$ a longer, 60-day observation time, they placed 20 zirconia ceramic implants in the tibiae of 5 male rabbits. They found an average bone-implant contact of $68.4 \% \pm 2.4 \%$. No gaps or fibrous tissue and no epithelial downgrowth were present at the interface. Wide marrow spaces were present, with some of them abutting on the implant surface. Aldini et al. achieved a BIC value of $55 \% \pm 27 \% .{ }^{27}$

Whereas surface nanostructural features were not taken into consideration in the last 2 studies mentioned, Sennerby and Meredith published a precise analysis of the connection of zirconium implant surface roughness with the results of achieved BIC. ${ }^{13}$ In the studies, the implants were divided into 3 groups depending on the degree of roughness. The studies were performed on a rabbit model, by applying the implants in the femoral and tibial area. The BIC results varied depending on the site of implantation. For implants applied to the femoral bone, seemingly more referential results were obtained $-46 \%$ for the $1^{\text {st }}$ group, $60 \%$ for the $2^{\text {nd }}$ and $70 \%$ for the $3^{\text {rd }}-$ whereas the BIC for implants applied to the tibia bone were much lower: $19 \%, 31 \%$ and $22 \%$, respectively. It seems, then, that the most preferential degree of zirconium implant surface roughness is different than in the case of titanium implants.

Depprich et al. designed a study to compare titanium implants of higher roughness with zirconium implants of lower roughness. ${ }^{28}$ For this purpose, 24 screw-type zirconium implants with acid-etched surfaces were used and compared to 24 implants made of titanium - SLA implants. The implants were inserted into the tibiae of $12 \mathrm{mini}-$ pigs. The histological results showed direct bone contact on the zirconium and titanium surfaces, which demonstrated that zirconium implants with modified surfaces result in osseointegration comparable to that of titanium implants.

In another study, the negative interaction of the bone tissue with zirconium implants after loading was shown. ${ }^{29}$ In the study, 1-phase zirconium implants, which required immediate loading, were used alongside 2-phase unloaded ones. Despite generally good BIC parameters, marginal defects of the alveolar process after implant loading were observed. This study demonstrated that a 2-phase implantation method is preferred with zirconium implants.

In another study, a total of 18 zirconium implants and 18 titanium implants, identical in shape, with acid-etched and sand-blasted surfaces were tested on a mini-pig model. The observation period was 4, 8 and 12 weeks. The histological observation did not reveal any statistically significant differences between zirconium and titanium SLA implants for peri-implant bone density and BIC ratio. There were 2 exceptions: the mean peri-implant bone density and $\mathrm{BIC}$ values of the control implants were always higher than those of the tested zirconia implants. The conclusion was that no detectable difference in osseointegration could be observed between the 2 types of implants. ${ }^{30}$ 


\section{Conclusions}

The results from our study suggest that zirconia implants with modified surfaces display features of osseointegration similar to those of titanium implants. These results are promising in using zirconia implants for dental applications in the future.

Typical presence of relatively thin bone trabeculae with highly vasculated medulla (Masson-Goldner staining $\times 80$ ).

\section{References}

1. Vishnu S, Kusum D. Advances in surface modification of dental implants from micron to nanotopography. Int J Res Dent. 2011;1:1-10.

2. Schwarz F, Mihatovic I, Shirakata Y, Becker J, Bosshardt D, Sculean A. Treatment of soft tissue recessions at titanium implants using a resorbable collagen matrix: A pilot study. Clin Oral Implants Res. 2014;25(1):110-115.

3. Evrard L, Waroquier D, Parent D. Allergies to dental metals. Titanium: A new allergen. Rev Med Brux. 2010;31(1):44-49.

4. De Wijs FL, Van Dongen RC, De Lange GL, De Putter C. Front tooth replacement with Tubingen (Frialit) implants. J Oral Rehabil. 1994;21: $11-26$.

5. Schulte W, d'Hoedt B. 13 Jahre Tubinger Implantat aus Frialit-Weitere Ergebnisse. Zeitschrift Zahnarzt Implant. 1988;3:167-172.

6. Hisbergues M, Vendeville S, Vendeville P. Zirconia: Established facts and perspectives for a biomaterial in dental implantology. J Biomed Mater Res. 2009;88(2):519-529.

7. Gahlert M, Gudehus T, Eichhorn S, Steinhauser E, Kniha H, Erhardt W. Biomechanical and histomorphometric comparison between zirconia implants with varying surface textures and a titanium implant in the maxilla of miniature pigs. Clin Oral Implants Res. 2007; 18(5):662-668.

8. Allegrini S Jr, Allegrini MR, Yoshimoto $M$, et al. Soft tissue integration in the neck area of titanium implants: An animal trial. J Physiol Pharmacol. 2008;59(Suppl 5):117-132.

9. Gedrange T, Mai R, Mack F, et al. Evaluation of shape and size changes of bone and remodelled bone substitute after different fixation methods. J Physiol Pharmacol. 2008;59(Suppl 5):87-94.

10. Mai R, Lux R, Proff P, et al. O-phospho-L-serine: A modulator of bone healing in calcium-phosphate cements. Biomed Tech. 2008;53(5): 229-233.

11. Kunert-Keil Ch, Gedrange T, Mai R, et al. Morphological evaluation of bone defect regeneration after treatment with two different forms of bone substitution materials on the basis of BONITmatrix. J Physiol Pharmacol. 2009;60(Suppl 8):57-60.

12. Donath $\mathrm{K}$, Breuner $\mathrm{G}$. A method for the study of undecalcified bones and teeth with attached soft tissues. The Säge-Schliff (sawing and grinding) technique. J Oral Pathology. 1982;11(4):318-326.

13. Sennerby L, Meredith N. Implant stability measurements using resonance frequency analysis: Biological and biomechanical aspects and clinical implications. Periodontology 2000. 2008;47:51-65.
14. Coelho PG, Granjeiro JM, Romanos GE, et al. Basic research methods and current trends of dental implant surfaces. J Biomed Mater Res B Appl Biomater. 2009;88:579-596.

15. Barrett JF, Keat N. Artifacts in CT: Recognition and avoidance. Radiographics. 2004;24:1679-1691.

16. Wennerberg A, Albrektsson T, Lausmaa J. Torque and histomorphometric evaluation of c.p. titanium screws blasted with 25- and 75microns-sized-particles of $\mathrm{Al}_{2} \mathrm{O}_{3}$. J Biomed Mater Res. 1996;30:251-260.

17. Larsson C, Thomsen $P$, Aronsson BO, et al. Bone response to surfacemodified titanium implants: Studies on the early tissue response to machined and electropolished implants with different oxide thicknesses. Biomaterials. 1996;17:605-616.

18. Buser D, Broggini N, Wieland M, et al. Enhanced bone apposition to a chemically modified SLA titanium surface. J Dent Res. 2004;83: 529-533.

19. Schwarz F, Herten M, Sager M, Wieland M, Dard M, Becker J. Histological and immunohistochemical analysis of initial and early osseous integration at chemically modified and conventional SLAs titanium implants: Preliminary results of a pilot study in dogs. Clin Oral Implants Res. 2007;18:481-488.

20. Gahlert M, Röhling S, Wieland M, Sprecher CM, Kniha H, Milz S. Osseointegration of zirconia and titanium implants: A histological and histomorphometrical study in the maxilla of pigs. Clin Oral Implants Res. 2009;20(11):1247-1253.

21. Bornstein MM, Valderrama $P$, Jones AA, Wilson TG, Seibl R, Cochran DL. Bone apposition around two different sandblasted and acid-etched titanium implant surfaces: A histomorphometric study in canine mandibles. Clin Oral Implants Res. 2008;19(3):233-241.

22. Hayashi K, Matsuguchi N, Uenoyama K, Sugioka Y. Re-evaluation of the biocompatibility of bioinert ceramics in vivo. Biomaterials. 1992;13:195-200.

23. Chang YS, Oka M, Nakamura T, Gu HO. Bone remodeling around implanted ceramics. J Biomed Mater Res. 1996;30:117-124.

24. Dubruille JH, Viguier E, Le Naour G, Dubruille MT, Auriol M, Le Charpentier Y. Evaluation of combinations of titanium, zirconia, and alumina implants with 2 bone fillers in the dog. Int J Oral Maxillofac Implants. 1999;14:271-277.

25. Stanic V, Aldini NN, Fini M, et al. Osteointegration of bioactive glasscoated zirconia in healthy bone: An in vivo evaluation. Biomaterials. 2002;23:3833-3841.

26. Scarano A, Di Carlo F, Quaranta M, Piattelli A. Bone response to zirconia ceramic implants: An experimental study in rabbits. J Oral Implantol. 2003;29:8-12.

27. Aldini NN, Fini M, Giavaresi G, et al. Osteointegration of bioactive glass-coated and uncoated zirconia in osteopenic bone: An in vivo experimental study. J Biomed Mater Res. 2004;68:264-272.

28. Depprich R, Zipprich H, Ommerborn M, et al. Osseointegration of zirconia implants: An SEM observation of the bone-implant interface. Head Face Med. 2008:4:25. https://doi.org/10.1186/1746-160X-4-25

29. Akagawa $Y$, Ichikawa $Y$, Nikai H, Tsuru H. Interface histology of unloaded and early loaded partially stabilized zirconia endosseous implant in initial bone healing. J Prosthet Dent. 1993;69(6):599-604.

30. Gahlert M, Roehling S, Sprecher CM, Kniha H, Milz S, Bormann K. In vivo performance of zirconia and titanium implants: A histomorphometric study in mini pig maxillae. Clin Oral Implants Res. 2012;23:281-286. 